\title{
PRICE STABILIZATION AND IPO UNDERPRICING: AN EMPIRICAL STUDY IN THE INDONESIAN STOCK EXCHANGE
}

\author{
Suad Husnan, Mamduh M. Hanafi \& Muhammad Munandar ${ }^{*}$ \\ Universitas Gadjah Mada \\ (suadhusnan@ugm.ac.id)
}

\begin{abstract}
We attempt to investigate IPO underpricing and stabilization activities. We find IPO underpricing of around 25\% in the Indonesia market. Return distribution for the first 30-trading days shows a positive skew, the distribution becomes closer to normality as the period lengthens. We then develop and test five algorithms to detect IPO intervention. An important goal of this paper is to develop an algorithm that will be able to detect IPO intervention using public data. We find that the number of closing prices that are equal to the offer prices and the skewness of the IPO return in the first 30-trading days are the 'best' stabilization measures. Having found "the best measures", then we investigate under what conditions IPO intervention is more intensive. We find that underwriters tend to stabilize more on more expensive IPOs.
\end{abstract}

Keywords: IPO, Indonesia, underpricing, stabilization

\section{INTRODUCTION}

IPO underpricing is a common phenomenon found in practically all the capital markets around the world. For example, in the Indonesian market, Utamaningsih (2013) found that IPO underpricing, calculated by the difference between the closing price on the first trading day, to the original offer price on the Indonesian Stock Exchange, averages around 30\%. Underpricing is considered as an implicit cost to the company issuing its shares to the public, in addition to being an explicit cost, such as the cost of underwriting. A company, issuing shares to the public loses an opportunity to obtain a larger amount of funds collected from the IPO sales.

Various theories have been advanced to explain the IPO underpricing. Baron (1982) developed a model based on asymmetric information between a company and its underwriter. The underwriter possesses better information than the company. The underwriter prefers to have a

\footnotetext{
* We thank anonymous referees for their comments and suggestions. We also thank participants of 2014 Faculty of Economics and Business seminar for Case and Research Results Dissemination.
}

lower offer price so as to be able to sell the shares more easily to public investors. Hence, the underwriter will prefer to set a lower offer price; which tends to increase underpricing. Using an asymmetry framework, other researchers argue that the IPO is a signal to the market. Good companies offer higher underpricing to investors to signal their quality. This signal is costly; it is difficult for poor companies to imitate. Thus the signal is credible. The company can benefit from the signal, for example, the company can be expected to receive a more favorable price when it issues seasoned equity offers.

Rock (1986) developed a winner's curse model to explain IPO underpricing. In his model, there are 2 types of investors: informed and uninformed investors. Informed investors will buy good IPOs and do not buy bad ones. Uninformed investors do not have good information about which IPO is good or bad. Uninformed investors buy both good and bad IPOs. As a result, informed investors will always gain at the expense of the uninformed investors. In an equilibrium setting, uninformed investors will eventually withdraw from the IPO market, leading to 
the collapse of that market. To keep uninformed investors participating in the IPO market, uninformed investors must be compensated. IPO underpricing is a form of compensation for uninformed investors to keep them in the IPO market.

Deliberate IPO underpricing is difficult to reconcile with reasonable logic and empirical evidence. Why is a company willing to give up about $30 \%$ of the 'money on the table'? This number is significant. The logic of Rock's (1986) model is also questioned, since empirical vidence shows that IPOs are generally oversubscribed. Why does the company need to provide compensation when there are so many potential buyers for its IPO? In general, models based on information asymmetry seem to receive little support.

Ritter (2002) argued that the most potential explanation for the IPO phenomenon may come from the agency theory and behavioral finance. The agency theory for IPOs explores several issues, such as how the IPO is allocated between institutional and individual investors (Aggarwal et al., 2002), stabilization activities in the IPO market (Aggarwal et al., 2002; Ruud, 1993), the effect of ownership structure on IPO performance (Brennan and Franks, 1997), and flipping activities on the first trading day of IPOs (Aggarwal, 2000; Wilhelm, 1999). Behavioral finance for IPOs discusses issues such as the prospect theory (Kahneman dan Tversky, 1979) for IPOs and market sentiment related to the IPO market (Cornell et al, 2006).

This research attempts to extend the literature on IPOs by investigating price stabilization on Indonesian IPOs. Price stabilization is an action to prevent or decrease the price fall for IPO stocks (Aggarwal, 2002). The action covers various mechanisms, such as share purchasing by the underwriter in secondary markets, discouraging flipping activities in IPO's market, IPO allocation (the underwriter allocates the IPO to investors who will not flip the IPO stocks), and other mechanisms as well. Although price stabilization is a promising explanation for the phenomenon of IPO underpricing, empirical research on this issue is relatively less known.
This paper attempts to fill this void. We also investigate various algorithms to detect price stabilization in IPO markets using public data. We consider 5 alternative algorithms: (1) the number of closing prices in the first 30 trading days that are equal to or higher than the offer prices, (2) the number of closing prices in the first 30 trading days that are equal to the offer price, (3) the ratio of return distribution for the first 30 trading days to that for the first $60-90$ trading days, (4) the skewness of the first 30 trading day return, and (5) the number of closing prices, in the first 30 trading days, that are above the offer prices and preceded by closing prices below the offer price on the previous day. ${ }^{1}$

We find that the return distribution for the first 30 trading days for IPOs on the Indonesian Stock Exchange is positively skewed, suggesting that there is price stabilization. This result is consistent with that of Ruud (1993). Then we compare the 5 price stabilization algorithms to determine which 1 is the best indicator to predict price stabilization. A natural approach is to compare price stabilization to the degree of IPO underpricing. Thus we regress various price stabilization algorithms on IPO underpricing. Our result show that the algorithms that uses the number of closing prices in the first 30 trading days that are equal to the offer price, and the degree of skewness of the IPO return in the first 30 trading days, predict IPO underpricing well. In the last part, we show that stabilization activities exist more in shares with a higher ratio of price to book value.

We organized our paper as follows. In the next section, we present the literature review, followed by the empirical results. The last section offers our conclusions.

\section{Literature Review}

IPO stabilization can be defined as the actions to prevent the IPO price from falling below its offer price. These actions can be done either with pre and/or aftermarket IPOs. Various premarket actions can be done, such as

\footnotetext{
${ }^{1}$ We consider more than five algorithms in this research. However, for brevity, we report only four algorithms in this paper.
} 
determining IPO allocations (allocate it to investors who will not flip the IPO), and discouraging flipping activities. Aftermarket actions are done after IPO trades in the secondary market. Aftermarket actions in many situations are closely related to premarket actions. Aggarwal (2002) showed 3 aftermarket stabilization actions: (1) 'pure' stabilization, in which the underwriters post bid prices not exceeding offer prices, (2) short covering from a short position taken before the IPO trades in the aftermarket. Underwriters initially sell shares in excess of the original IPO amount offered, effectively taking a short position. Then this short position will be covered either by exercising the overallotment option and/or short covering in the aftermarket, (3) underwriters penalize investors who flip the IPO quickly, referred to as a penalty bid. Short covering has an advantage compared to pure stabilization, since underwriters do not have to disclose this plan. Aggarwal (2002) showed that pure stabilization is actually relatively minor compared to the other means.

The literature offers several explanations on why underwriters provide IPO price support (Lewellen, 2006): Price support as a reward to investors and as a bonding mechanism, price support as a form of price manipulation, and price support to maintain the underwriter's reputation. In the first explanation, underwriters provide compensation to investors, more specifically uninformed investors. Chowdhry \& Nanda (1996) based on Rock's (1986) model, argue that stabilization is an alternative to compensation to uninformed investors in the winner's curse setting for the IPO. A commitment to buy an IPO at the offer price is effectively equal to giving a 'put' option to investors, which is an additional value to investors who buy the IPO, especially uninformed investors. Uninformed investors, in Rock's model (1986) are parties who will likely end up buying poor IPOs. Chowdhry \& Nanda (1996) argue that stabilization may be more efficient than underpricing in compensating uninformed investors for the problem of adverse selection costs.

In the second explanation, underwriters stabilize IPO markets to manipulate prices.
Hanley et al. (1993) argued that stabilization activities may increase stock prices and disguise poor IPOs. However, this argument may be questionable since it is hard to deceive rational investors. One may argue that while stabilization may not deceive informed investors, but it could well deceive uninformed investors. Schultz \& Zaman (1994) argued that stabilization can be expected to increase the aftermarket price. This can be done by reducing the supply of IPO shares. Price support at the offer price can be expected to reduce cascading from price decline, since the underwriter promises to buy the IPO at offer price.

In the third explanation, the underwriter attempts to maintain his/her reputation. An overpriced IPO may signal the underwriters' incompetency, lack of effort, and honesty. The incident of IPO overpricing may affect the underwriters' future revenue, and may have adverse impacts on the underwriter. Beatty \& Ritter (1986) and Dunbar (2000) showed that an underwriter that prices IPOs inaccurately loses market share, and experiences a decline in the underwriters' market value in the subsequent period. Larger underwriters may stabilize to a greater extent than smaller ones since their stake is larger, and also the ability to stabilize at greater extent is stronger for larger underwriters than for smaller ones.

Stabilization activities are difficult to measure, and even to detect. Lack of data and transparency from the industry are probably the main causes of this difficulty. Using proprietary data, Lewellen (2006) developed 3 measures of stabilization activities. First, Lewellen (2006) identified unusually high selling volumes from investors to underwriting syndicates and then calculated changes in the market maker's inventory position after the offer. The idea is that any attempt to stabilize the market (purchase shares) will inflate the share price to an artificially higher level. Rational investors recognize this situation, and start taking advantage by selling shares at higher than normal prices. This action leads to a decrease in the market maker's inventory position. This change in the market maker's inventory position are used as a proxy for stabilization activities. 
Second, a stickiness in the stock price during a stabilization period may indicate stabilization activities. Underwriters attempt to prevent the price declining to below the offer price. They will allow the price to decline only after efforts to maintain prices fail. This action creates a stickiness in a stock price during stabilization periods. Third, Lewellen (2006), in a similar spirit to Ruud (1993) and Prabhala \& Puri (1999), used a dummy with the value of 1 for IPOs that close at offer price on the first trading day (stabilized) and 0 for IPOs that close below offer price (not stabilized). Ruud (1993) and Prabhala \& Puri (1999) found that the return distribution for IPO was almost censored at 0 . The return distribution for IPO returns is heavily skewed to the right (positive skewed). This method assumes that no stabilization activities occurred for the IPOs that closed below or even above the offer price.

Lewellen (2006) showed that stabilization activities are more complex than those that can be described in the third measure. However, the third measure has the advantage of its novelty. This paper takes that spirit of novelty to measure stabilization activities. Specifically, we attempt to measure stabilization activities using published data, which are the daily closing prices. Once we are able to develop such a measure, we will be able to detect and measure stabilization activities using a simple, yet powerful technique.

In the Indonesian market, stabilization by underwriters is allowed by the Bapepam (Badan Pengawas Pasar Modal or Indonesia Capital Market Supervisory Agency). Practically, in many countries, IPO stabilization is probably the only non-natural capital market transaction that is allowed. Stabilization activities are regulated by a Capital Market decree, (Number 88/PM/ 1996), which was then replaced by a revised decree in 2009. The regulation basically allows market stabilization for the first 30 trading days of the IPO. Underwriters have to state any stabilization plans in the prospectus. The IPO intervention prices have to be at the offer price.

\section{EMPIRICAL RESULTS}

\section{Sample and Data}

We used IPOs in the Indonesian market from 1995 to 2012. 1995 was the start of the JATS (Jakarta Automated Trading System), where all transactions are recorded electronically. We do not use IPOs from before 1995, since this older IPO data are more difficult to verify their validity. We collected 231 IPOs for our sample. For regression analysis in the section of the determinants of stabilization activities, we used only samples with complete data. For this section, we were able to collect around 140 IPOs for our sample. We collected the first day closing price of IPOs, the offer price, the size of the IPO (both in Rupiah and in shares), the percentage of the IPO relative to the total outstanding shares, the ratio of Price to Book Value, and the daily closing price for up to 120 trading days in the IPO aftermarket. The data are collected from the Indonesian Stock Exchange and IPO prospectuses.

\section{Underpricing and Return Distribution}

Table 1 reports the underpricing (initial return) and aftermarket return for our sample. Aftermarket returns consist of 5, 30, 60, and 90 day returns. The table shows that the mean of underpricing (initial return) in the Indonesian market is around $23 \%$. This number is lower than the number reported by Utamaningsih (2013). The median for the initial return is lower than the mean, suggesting that the distribution of the initial return is not normal. The distribution seems to have a positive skew. Normal distribution would show little difference between the mean and the median.

5 day aftermarket returns shows similar characteristics to the initial returns. The median is lower than the mean, suggesting a positive skew. The maximum return is around $187 \%$, while the minimum is around $47 \%$, suggesting overpricing of this IPO. 30, 60 and 90 day aftermarket returns show a trend toward normal distribution. The averages tend to move lower as the number of days grows larger. The average for 90 day aftermarket returns is around $18 \%$, which is much lower than the initial returns. The 
Table 1. IPO Initial Return and Aftermarket Return in the Indonesian Stock Exchange

Initial return is calculated as $\ln$ (price at period t/offer price). 5-day return is calculated as ln (price at day 5 relative to first trading day/offer price). Similar calculation is done for 30, 60, and 90 day return. The sample consists of IPOs from year 1995 to 2012 in the Indonesian Stock Exchange.

\begin{tabular}{lccccc}
\hline & Initial Return & 5-dayreturn & 30-day return & 60-day return & 90-day return \\
\hline Mean & 0.2306 & 0.2714 & 0.2562 & 0.2150 & 0.1795 \\
Median & 0.1542 & 0.1445 & 0.1432 & 0.1178 & 0.1398 \\
Standard Deviation & 0.3105 & 0.3909 & 0.4828 & 0.5757 & 0.6277 \\
Minimum & -0.7178 & -0.4745 & -0.8824 & -1.1982 & -1.7987 \\
Maximum & 1.7579 & 1.8718 & 2.1401 & 2.0794 & 2.0149 \\
Number of Observation & 231 & 232 & 232 & 231 & 231 \\
\hline \multicolumn{2}{l}{ Source: Center for Business and Economic Data, Faculty of Economics and Business, Universitas Gadjah Mada }
\end{tabular}

differences between the mean and median of aftermarket returns tends to grow smaller as the aftermarket lengthens, suggesting that return distribution conforms more closely to normal distribution as the time period grows.

Lower returns in the 90 day aftermarket suggest price reversal of the IPO. Initial returns show larger returns and reverses in the aftermarket. Interestingly, returns in the aftermarket period decrease gradually as the length of aftermarket period increases. This pattern seems to be consistent with the tendency to move towards a normal distribution as the length of aftermarket period increases.

Table 2 shows the initial return distribution based on the year of the IPO. Interestingly we find that the initial return is very volatile. Initial returns have negative values in 1995 and 2011. In 2001 and 2010, means of the initial return have the largest value. Table 3 shows the initial return distribution based on the type of industry. Our definition of industry follows that of the Indonesian Stock Exchange. Again, the amount of the initial return varies among the industries. Real Estate and Basic Chemicals record the largest IPO initial return. The initial return does not seem to be homogenous across the various industries and years. Ritter \& Welch (2002), using US data, found that the initial return varies across the years. There were fewer IPOs in the US from 1935 to 1959 than in 1969 alone. La Porta et al. (1997) reported wide differences in IPO activities across countries. This pattern leaves questions on why in certain years there are more IPOs and higher initial returns than in other years, why initial returns are higher in some industries than in other industries, and why there are more IPOs in some countries than in other countries.

\section{Return Distribution of IPO returns}

Stabilization activities are difficult to measure directly. Limited data and the lack of transparency from the underwriter prevented us from measuring stabilization directly. This paper attempts to measure intervention activities indirectly, using published data. Specifically, we attempt to investigate patterns of IPO returns surrounding the IPO period. Bapepam (Supervisory Agency for Indonesia Stock Market) allows intervention by the underwriter for the first 30 days of IPO trading activities in the secondary market. We believe that such activities will be reflected in the return pattern of the IPO, such as the distribution of the IPO return (Ruud, 1993). For example, if intervention activities do affect the return distribution, then we can expect that return distribution to differ in the days beyond 30, (for example in the first 60 to 90 trading days in the secondary market) from that in the first 30 days in the secondary market. That first 30 trading day period is when intervention is allowed. We can expect that the return distribution in the first 30 trading days will depart from non-normality distribution (a more positive skewness), while return distribution in days 60 to 90 , which is a 'normal' period, will conform more closely to the normal distribution. The ratio of the degree of skewness in the normal to 
Table 2. Initial Return Distribution Based on the IPO's Year

This table presents initial return based on the year of the IPO. Initial return is calculated as ln (price at period t/offer price). The sample consists of IPOs from 1995 to 2012 in the Indonesian Stock Exchange.

\begin{tabular}{ccccccc}
\hline Year & Mean & Median & $\begin{array}{c}\text { Standard } \\
\text { Deviation }\end{array}$ & Minimum & Maximum & $\begin{array}{c}\text { Number of } \\
\text { Observation }\end{array}$ \\
\hline 1995 & -0.0009 & 0.0043 & 0.1513 & -0.2963 & 0.3646 & 14 \\
1996 & 0.1047 & 0.0732 & 0.1185 & -0.0870 & 0.3857 & 16 \\
1997 & 0.0807 & 0.1301 & 0.2123 & -0.7178 & 0.4055 & 30 \\
1998 & 0.1069 & 0.0877 & 0.3345 & -0.2513 & 0.7138 & 6 \\
1999 & 0.2745 & 0.1610 & 0.2568 & 0.0000 & 0.7885 & 8 \\
2000 & 0.3823 & 0.2451 & 0.3341 & -0.0513 & 1.0647 & 21 \\
2001 & 0.5011 & 0.3765 & 0.4970 & -0.3567 & 1.7579 & 31 \\
2002 & 0.2452 & 0.2546 & 0.2749 & -0.3939 & 0.5306 & 22 \\
2003 & 0.0637 & 0.0353 & 0.1149 & -0.0645 & 0.2683 & 6 \\
2004 & 0.1549 & 0.0912 & 0.1632 & 0.0000 & 0.5188 & 12 \\
2005 & 0.1245 & 0.0852 & 0.1457 & -0.0526 & 0.3895 & 8 \\
2006 & 0.3016 & 0.2965 & 0.1830 & 0.0377 & 0.5831 & 12 \\
2007 & 0.2310 & 0.1782 & 0.2308 & -0.1376 & 0.5306 & 25 \\
2008 & 0.2187 & 0.2007 & 0.2200 & -0.1863 & 0.5306 & 19 \\
2010 & 0.5278 & 0.5278 &. & 0.5278 & 0.5278 & 1 \\
2011 & -0.0101 & -0.0101 &. & -0.0101 & -0.0101 & 1 \\
\hline
\end{tabular}

Source: Center for Business and Economic Data, Faculty of Economics and Business, Universitas Gadjah Mada

Table 3. Initial Return Distribution Based on the type of Industry

This table presents initial return based on the year of the IPO. Initial return is calculated as $\ln$ (price at period t/offer price). The sample consists of IPOs from 1995 to 2012 in the Indonesian Stock Exchange. Industry categories follow the Indonesian Stock Exchange definition.

\begin{tabular}{lcccccc}
\hline \multicolumn{1}{c}{ Industry } & Mean & Median & $\begin{array}{c}\text { Standard } \\
\text { Deviation }\end{array}$ & Minimum & Maximum & $\begin{array}{c}\text { Number of } \\
\text { Observation }\end{array}$ \\
\hline Miscellaneous Manufacturing & 0.2427 & 0.1431 & 0.3306 & -0.3075 & 0.7178 & 13 \\
Consumer Goods & 0.0831 & 0.0660 & 0.2239 & -0.2963 & 0.6444 & 11 \\
Basic Chemicals & 0.3018 & 0.1884 & 0.3236 & -0.0870 & 0.9651 & 20 \\
Infrastructure, Utility, and Transportation & 0.0287 & 0.0241 & 0.0312 & 0.0000 & 0.0619 & 3 \\
Financials & 0.1688 & 0.1398 & 0.3056 & -0.7178 & 1.0116 & 39 \\
Trades and Services & 0.2955 & 0.1823 & 0.4461 & -0.3567 & 1.7579 & 31 \\
Mining & 0.1389 & 0.0426 & 0.2688 & 0.0000 & 0.7397 & 7 \\
Agriculture & 0.3155 & 0.1823 & 0.3350 & 0.0000 & 1.0598 & 9 \\
Real Estate & 0.4087 & 0.2231 & 0.4315 & -0.1252 & 1.3106 & 15 \\
Others & 0.2060 & 0.1695 & 0.2057 & -0.1863 & 0.5831 & 84 \\
\hline Soln
\end{tabular}

Source: Center for Business and Economic Data, Faculty of Economics and Business, Universitas Gadjah Mada

non-normal period may measure the degree of IPO intervention in the secondary market.

Table 4 shows the distribution of IPO returns for the initial return and the aftermarket returns in the secondary market. We report 5, 30, 60, and 90 day aftermarket returns.

The table seems to confirm our prediction. Initial returns show a positive skewness distribution. The values of the skewness for returns up to 30 days are positive. As IPO intervention diminishes $^{2}$, the skewness becomes closer to zero, suggesting that return distribution moves closer to normal distribution. The value of the skewness for normal distribution is zero. Kurtosis tends to decrease as the length of the period increases. While the value of kurtosis for normal distribution is 3 , the decrease in kurtosis

\footnotetext{
${ }^{2}$ We use the first 30 trading days as a period of IPO intervention. Bapepam regulation states that the underwriter may intervene in IPO trading during the first 30 trading days.
} 
Table 4. Kurtosis, Range, and Skewness of the IPO Return

Initial return is calculated as $\ln$ (price at period t/offer price). 5-day return is calculated as ln (price at day 5 relative to first trading day/offer price). Similar calculations are done for the 30, 60, and 90 day returns. The sample consists of IPOs from 1995 to 2012 in the Indonesian Stock Exchange. Kurtosis, range, and skewness, are calculated cross-sectionally for our sample IPOs.

\begin{tabular}{lccccc}
\hline & Initial Return & 5-day return & 30-day return & 60-day return & 90-day return \\
\hline Kurtosis & 3.1073 & 1.5883 & 1.2620 & 0.6932 & 0.5000 \\
Range & 2.4757 & 2.3463 & 3.0225 & 3.2777 & 3.8136 \\
Skewness & 1.1737 & 1.2169 & 0.9484 & 0.6922 & 0.2592 \\
\hline
\end{tabular}

Source: Center for Business and Economic Data, Faculty of Economics and Business, Universitas Gadjah Mada and Authors' calculation

for the aftermarket returns suggests that return distribution widens. The highest value for kurtosis for the initial return seems to suggest that initial returns peak at a certain value, which we believe is zero return (closing price is equal to offer price). This pattern seems to support the stabilization hypothesis for the IPO market.

\section{Measures of Stabilization Activities}

As explained in the previous section, we attempted to measure the degree of stabilization in the IPO market. We showed that the return distribution for IPO markets in the first 30 trading days does not conform to normal distribution. In this section, we attempt to develop further measures for IPO stabilization. We develop 5 algorithms to measure the degree of stabilization. First, during the first 30 trading days, we count the number of closing prices that are equal to the offer price. Bapepam regulations state that the underwriter is allowed to support the IPO stock at its offer price. In other words, the underwriter could bid the IPO stock at a maximum of its offer price. Thus, this regulation provides us with a first and simple clue to measure the degree of stabilization.

If an IPO stock closes below its offer price, then we believe that the underwriter has not intervened with the IPO stock. If the closing price is above the offer price, then this method argues that the underwriter also does not intervene with the stock. Intervention or stabilization only exists if the closing prices are equal to the offer prices. In this situation, the underwriter has attempted to support the IPO stock, to prevent the price from going below its offer price.
In the second algorithm, during the first 30 trading days, we calculate the number of closing prices that are the same or higher than the offer price. During the first 30 days, attempts by the underwriter to support the IPO price will result in prices either being the same or higher than the offer price. Closing prices do not have to be the same as the offer price for stabilization conditions.

In the third algorithm, we develop the following method. If the closing price of the IPO stock at day $t$ is above the offer price, and the closing price at day $\mathrm{t}-1$ is below the offer price, then that indicates there have been stabilization activities. The underwriter attempts to maintain his/her reputation, so the underwriter will attempt to support the IPO price to stop it from falling below its offer price. With this method, we argue that stabilization activities start the next day. Thus the situation in which the closing price is below the offer price becomes a trigger for the stabilization activities.

The fourth algorithm uses the skewness measure for the return distribution of the first 30 trading days. As explained in the previous section, skewness may indicate support to maintain the price of the IPO stock. Our fifth algorithm uses the ratio of skewness in the first 30 trading days to the skewness in days 60 to 90 relative to the initial trading. In the previous section, we showed that return distribution for the first 30 trading days departs significantly from normal distribution, while the return distribution for days after 30 relative to the initial trading conforms more closely to normal distribution. The degree of non-normality in the first 30 
trading days will be captured by the ratio of skewness in the first 30 trading days to the skewness in days 60 to 90 . We expect that this ratio will be able to measure the degree of IPO stabilization in the first 30 trading days.

Table 5 reports descriptive statistics for the 5 algorithms to detect IPO stabilization.

For our sample, the mean of daily closing prices during the first 30 days that were equal to the offer price was 1.94 days. During the first 30 trading days, most of the IPOs in our sample had closing prices that were higher than their offer prices. The mean for the second measure of stabilization is 21.59 days, while the median is 29 days. The incident of positive returns at day $\mathrm{t}$ is higher than the offer price following negative return at day $\mathrm{t}-1$, the third measure of stabilization, is not common. The average for this measure is only 0.30 . The maximum for this measure is 4 . The fourth stabilization measure uses the skewness of the return distribution for the first 30 trading days. The average of this skewness is positive which is consistent with our findings in the previous section. The number in this table is different from that in table 2 , since the methodology in this table is different. The last measure shows a negative number of -1.31 . We note extreme values for this measure, from -166.17 for the minimum to 45.55 for the positive number.

\section{In Search of a Good Stabilization Measure}

One of our goals in this paper was to formulate an algorithm to detect stabilization activities using public data. We already proposed 5 algorithms to detect stabilization activities. In this section, we attempt to validate the 5 algorithms we developed in the previous section. Stabilization activities are difficult to observe directly, hence we attempt to validate the measures indirectly. Specifically, we will correlate the measures with other variable(s) that are expected to measure stabilization activities. We chose IPO underpricing as the candidate. The literature shows that underpricing and stabilization activities are closely related (Ruud, 1993; Lewellen, 2006). The objective of stabilization is to prevent the IPO prices from falling below the offer price, hence to create a positive initial return (or IPO underpricing). Thus, intuitively we expect a positive relationship between our measures and underpricing, should the measures be valid.

Table 6 reports the regression results of various stabilization measures on IPO underpricing.

Table 5. Descriptive Statistics For Stabilization Measures

This table reports descriptive statistics for stabilization measures. In Stab1, we use the number of closing prices from day1 to 30 that are equal to or higher than the offer price. In Stab2, we calculate the number of closing prices that are equal to the offer price. In Stab3, we count the number of the following incidents: closing price at day $t$ is above the offer price, preceded by closing price at day $t-1$ being below the offer price. In Stab4, we use skewness of the IPO return during the first 30 trading days (day1 to 30). In Stab5, we use a ratio of the skewness of the IPO return during the first 30 trading days to that in trading days 60-90. Return is calculated as ln (closing price at day t / offer price). Independent variable is initial return, calculated as ln (closing price at first trading day/offer price).

\begin{tabular}{lccccc}
\hline & Stab1 & Stab2 & Stab3 & Stab4 & Stab5 \\
\hline Mean & 1.94 & 21.59 & 0.30 & 0.019 & -1.31 \\
Median & 0 & 29 & 0 & 0.041 & -0.047 \\
Standard deviation & 5.64 & 11.53 & 0.67 & 1.058 & 15.38 \\
Minimum & 0 & 0 & 0 & -5.420 & -166.17 \\
Maximum & 29 & 29 & 4 & 2.711 & 45.55 \\
Number of observation & 247 & 247 & 247 & 225 & 222 \\
\hline
\end{tabular}

Source: Center for Business and Economic Data, Faculty of Economics and Business, Universitas Gadjah Mada and Authors' calculation 
Tabel 6. The Effect of Stabilization on IPO Underpricing

This table reports Ordinary Least Square regression results of various stabilization measures on IPO underpricing. We use the following algorithms to measure stabilization activities. In column (1), we use the number of closing prices from day1 to 30 that are equal to or higher than the offer price. In column (2), we calculate the number of closing prices that are equal to the offer price. In column (3), we count the number of the following incidents: the closing price at day $\mathrm{t}$ is above the offer price, preceded by the closing price at day $\mathrm{t}-1$ being below the offer price. In column (4), we use the skewness of the IPO return during the first 30 trading days (day1 to 30). In column (5), we use a ratio of the skewness of the IPO return during the first 30 trading days to that in trading days 60-90. Return is calculated as $\ln$ (closing price at day t/offer price). Dependent variable is initial return, calculated as $\ln$ (closing price at first trading day/offer price).***,**, and ${ }^{*}$ denote significance at $1 \%$, $5 \%$, and $10 \%$ level, respectively.

\begin{tabular}{lccccc}
\hline & $(1)$ & $(2)$ & $(3)$ & $(4)$ & $(5)$ \\
\hline Intercept & $0.2455^{* * *}$ & $-0,0773$ & $0.2480^{* * *}$ & $0.2278^{* * *}$ & $0.2293^{* * *}$ \\
& $(<0.0001)$ & $(0.1389)$ & $(<0,0001)$ & $(<0,001)$ & $(<0,0001)$ \\
Stabilization & $-0.0119^{* * *}$ & $0,0130^{* * *}$ & $-0,0842^{* *}$ & 0,0256 & -0.0008 \\
Measure & $(0.0031)$ & $(<0.001)$ & $(0,0140)$ & $(0,2648)$ & $(0.5814)$ \\
\hline Adj R-square & 0.00332 & 0,1436 & 0,0217 & 0,0011 & -0.0032 \\
F value & $8.92 * * *$ & $39.73^{* * *}$ & $6.13^{* *}$ & 1.25 & 0.30 \\
(prob) & $(0.0031)$ & $(<0.001)$ & $(0,014)$ & $(0.2648)$ & $(0.5814)$ \\
$\mathrm{N}$ & 231 & 231 & 231 & 223 & 220 \\
\hline
\end{tabular}

Source: Center for Business and Economic Data, Faculty of Economics and Business, Universitas Gadjah Mada and Authors' calculation

The table shows that the second and fourth measures have positive regression coefficients as expected. The other measures have negative regression coefficients. However further inspection shows that only the second measure, which is the total number of days in the first 30 trading days in which closing prices are equal to the offer price, shows a positive and significant regression coefficient. The other measures show either negative significant regression coefficients or insignificant positive ones. We conclude that the total number of closing prices that are equal to the offer price is the best measure of IPO stabilization activities.

\section{Determinants of Stabilization Activities}

Having established the "valid" stabilization measure, in this section we want to investigate in which conditions the underwriter intervenes in the IPO market more intensely. In other words, we want to investigate variables that affect an IPO's stabilization. We consider 5 variables in this section: the total number of IPO shares, the IPO's offer price, the total value of the IPO in Rupiah, the percentage of the IPO relative to the total outstanding shares, and the underwriters' reputation. Table 7 shows descriptive statistics for the variables of interest in this section.

The average offer price is 750 Rupiah, which is around 7.5 US cents (\$0.075). This amount is definitely considered a penny stock by US standards. The percentage of the IPO is around $25 \%$, which is similar to $30 \%$ of the average shares sold to the public in Indonesia. The size of the shares underwriting is calculated for each underwriter during the period of this study. The amount is probably not a perfect measure since the amount for this variable covers various years, and we do not deflate the amount for this variable. This limitation also holds for other variables, such as the IPO size in Rupiah.

We attempt to investigate the variables that affect stabilization activities using a regression technique. We consider 3 variables: the information asymmetry variables, the pricing variables, and the underwriters' reputation. Benveniste et al. (1996) and Chowdhry \& Nanda (1996) used an information asymmetry framework in their IPO underpricing model. Chowdhry \& Nanda (1996) showed that underpricing is needed to compensate uninformed investors in the winner's curse setting of Rock's (1986) model. Benveniste et al. (1996) modelled information asymmetry between underwriters and investors. 
Table 7. Descriptive Statistics for IPO size, IPO percentage, Offer Price, and Price to Book Value, Underwriters Proceeds

This table shows descriptive statistics of the IPO size, the offer price, the percentage of IPO, and the Price to Book Value. IPO size consists of the IPO size in millions of shares and in billions of Rupiah. IPO percentage is the percentage of shares offered to the public by the IPO relative to the total outstanding shares. Total underwriter IPO proceed is accumulated during the period of study. This variable is used as a proxy for the underwriters' reputation. Price to Book Value is a ratio of offer price to book value of the company stated in its IPO prospectus.

\begin{tabular}{|c|c|c|c|c|c|c|}
\hline & Mean & Median & $\begin{array}{l}\text { Standard } \\
\text { deviation }\end{array}$ & Minimum & Maximum & $\mathrm{N}$ \\
\hline IPO size (in millions of shares) & $36,099,908$ & 130 & 268,059,662 & 1 & $2,847,433,500$ & 151 \\
\hline IPO offer price (Rp) & 750 & 500 & 823 & 100 & 4,650 & 150 \\
\hline IPO size (billion Rp) & $8,773,486$ & 60 & $54,769,368$ & 0 & $455,589,360$ & 151 \\
\hline Percent (\%) & 25.72 & 25 & 10.57 & 0.38 & 66.67 & 148 \\
\hline $\begin{array}{l}\text { Shares underwriting size } \\
\text { (million shares) }\end{array}$ & $61,561,297$ & 199,237 & $144,522,593$ & 0 & $561,859,248$ & 147 \\
\hline Price to Book Value & 2.17 & 1.60 & 1.80 & -2.50 & 11.58 & 153 \\
\hline
\end{tabular}

Source: Center for Business and Economic Data, Faculty of Economics and Business, Universitas Gadjah Mada and Authors' calculation

A commitment to stabilize the IPO at the offer price is needed to prevent investors' losses from overpriced IPOs. The larger the information asymmetry, the larger the need for stabilization; hence we expect a positive relationship between information asymmetry and stabilization activities (Lewellen, 2006). We use the IPO's size as a proxy for information asymmetry. We have 2 variables that measure the IPO's size: the IPO size in millions of shares and the IPO size in billions of Rupiah. Both variables have a strong correlation, which may lead to the problem of multicollinearity. We chose IPO size in millions of shares as the measure of IPO size.

The offer price may affect stabilization activities. A higher offer price may result in IPO overvaluation. In the Benveniste et al. (1996) model, underwriters stabilize as a commitment to prevent investors' losses from overpriced IPOs. The probability of price decreases in the aftermarket for this IPO is higher than those with a low offer price. Stabilization activities in this situation can be expected to be more intense. Hence we expect a positive relationship between the offer price and stabilization activities. We have 2 measures for the offer price: the offer price in Rupiah and the offer price in relative terms. In relative terms, we use the ratio of price to book value (PBV). Again, we have to choose 1 as a proxy for the offer price. We chose the price to book value over the offer price in Rupiah as our proxy for the offer price.

Another variable that may affect stabilization activities is the underwriters' reputation. Lewellen (2006) showed that underwriters' reputations affect price stabilization. As explained in the previous section, a negative return in the IPO aftermarket may provide negative signals about the underwriters to investors: incompetent, poor commitment, lack of effort. These negative signals may have an adverse impact on the underwriters' business. This argument seems to have support from empirical evidence. For example, Dunbar (2000) found that larger underwriters lost their market share by significant amounts as a consequence of inaccurately priced IPOs. We may predict that the underwriter will attempt to maintain his/her reputation using price stabilization. Price decrease in the underwritten IPO may damage their reputation, so the underwriters will be more active to stabilize the IPO's price in the aftermarket. We expect that underwriters with good reputations will stabilize the IPO more intensely than those with a worse reputation. The stake is larger for those with a higher reputation. We expect to have a positive relationship between the underwriters' reputation and stabilization activities. We use the amount of IPOs underwritten during the period of our study as a proxy for the underwriters' 
reputation. The larger the number of IPOs an underwriter underwrites, the higher the reputation of that underwriter. Specifically, we accumulated the amount of IPOs for each underwriter during the period of our study. Then we calculated the average of the accumulated IPOs. We assign a dummy variable of 1 for the underwriters with accumulated IPOs higher than the average, and zero otherwise. Underwriters with a dummy variable of one have a higher reputation than those with the zero value.

Table 8 shows the regression results. Overall, regression analyses do not seem to provide convincing results. However, there is an indication that the Price to Book Value has a positive relationship with stabilization activities. In column (3), the regression coefficient for Price to Book Value shows a positive and significant sign. Underwriters seem to intervene more intensely for the more expensive IPOs. The more expensive IPOs may create higher uncertainty, and higher information asymmetry. Thus our results seem to support underpricing models that are based on asymmetry framework (Chowdhry \& Nanda, 1996; Benveniste et al., 1996). Our results are not consistent with those of Lewellen (2006) who found no support for underpricing models based on asymmetric information, but did find support for underwriters' reputations. Lewellen (2006) founds that larger investment banks stabilize more than smaller ones. Further, Lewellen (2006) showed that retail investment banks stabilize even more.

\section{CONCLUSION}

We attempted to investigate IPO underpricing in the Indonesian market, and develop measures for stabilization activities in the IPO market. We found that IPO underpricing in the Indonesian market is around $25 \%$. The distribution of the IPO return is heavily positively skewed. The distribution becomes closer to normality as the periods are lengthened. Thus the distribution for the initial return is more positively skewed than that for 5,30 , and 90 day returns. We found that the number of days in which the closing prices

Table 8. Regression Results of the Determinants of Stabilization Activities

This table reports Ordinary Least Square regression results of the various determinants of stabilization activities. In column (1) and (2), we use the number of closing prices during the first 30 trading days that are equal to the offer price. In column (3) and (4), we use the skewness of the daily return of the IPO during the first 30 trading days. The Price to Book Value is calculated as the offering price divided by book value in the year of going public. For underwriters' reputation, we use a dummy with the value of 1 for underwriters that have total IPO proceeds during our period of study higher than the mean of IPO proceed, and 0 otherwise. IPO size is the number of millions of shares of the IPO. The percentage is the percent of the IPO relative to total outstanding shares. $* * *, * *$, and $*$ denote significance at $1 \%, 5 \%$, and $10 \%$ level, respectively.

\begin{tabular}{lcccc}
\hline & $(1)$ & $(2)$ & $(3)$ & $(4)$ \\
\hline Intercept & $22.7044^{* * *}$ & $24.27344^{* * *}$ & 0.15432 & -0.14152 \\
& $(<.0001)$ & $(<.0001)$ & $(0.6105)$ & $(0.4033)$ \\
Price to Book Value & -0.06836 & -0.10879 & 0.07459 & $0.07544^{*}$ \\
& $(0.8864)$ & $(0.812)$ & $(0.1157)$ & $(0.0946)$ \\
Underwriters' reputation & -1.48504 & -1.04476 & 0.02799 & -0.0194 \\
& $(0.4475)$ & $(0.5711)$ & $(0.8799)$ & $(0.9125)$ \\
IPO size & 0.17859 & & -0.0223 & \\
& $(0.4088)$ & & $(0.3011)$ & \\
IPO percentage & 0.02226 & & $-0.00669(0.4012)$ & \\
& $(0.7879)$ & & & \\
\hline Adjusted R-Square & 0.08 & 0.0029 & 0.0319 & 0.0198 \\
F-value & 0.28 & 0.21 & 1.13 & 1.42 \\
(prob) & $(0.8893)$ & $(0.8108)$ & $(0.3448)$ & $(0.2442)$ \\
$\mathrm{N}$ & 143 & 145 & 141 & 143 \\
\hline
\end{tabular}

Source: Center for Business and Economic Data, Faculty of Economics and Business, Universitas Gadjah Mada and Authors' calculation 
are equal to the offer price, and the skewness of the first 30 day return, are the 'best' measures of stabilization activities. There is an indication that underwriters stabilize more the more expensive the IPO is.

We believe that this study on IPO stabilization provides a promising future. As data become more easily available, the study can be extended in several directions. For example, transaction data can be used to study the intraday price behavior during first day or first 30 trading days in the aftermarket, in which stabilization activities are conducted. Various types of underwriters (for example retail or institutional underwriters) may have different stabilization behaviors. We leave these issues for future research.

\section{REFERENCES}

Aggarwal, Reena, 2000, "Stabilization activities by underwriters after initial public offers". Journal of Finance, 55, 1075-1103.

Aggarwal, Reena, Nagpurnanand R. Prabhala, and Manju Puri, 2002, "Institutional allocation in initial public offers: Empirical evidence”. Journal of Finance 57, 1421-1442.

Baron, D.P., 1982, “A model of the demand for investment banking, reputation, and the underpricing of initial public offers". Journal of Financial Economics 24, 343-362.

Beatty, Randolph P., and Jay R. Ritter, 1986, "Investment banking, reputation, and the underpricingof initial public offers". Journal of Financial Economics 15, 213-232.

Benveniste, Lawrence M., Walid Y Busaba, and William J. Wilhelm, 1996, "Price stabilization as bonding mechanism in new equity issues". Journal of Financial Economics 42, 223-256.

Brennan, Michael J., and J. Franks, 1997, "Underpricing, ownership and control in initial public offerings of equity securities in the UK”. Journal of Financial Economics 45, 391-413.

Carter, Richard B., Frederick H. Dark, and Ajai K. Singh, 1998, "Underwriter reputation, initial returns, and the long-run performance of IPO stocks”. Journal of Finance 53, 285311.

Carter, Richard B., and Steven Manaster, 1990, "Initial public offers and underwriter reputation”. Journal of Finance 45, 1045-1067.

Chowdhry, Bhagwan, and Vikram Nanda, 1996, "Stabilization, syndication, and pricing of IPOs”. Journal of Financial and Quantitative Analysis 31, 25-42.

Cornell, F., D. Goldreich, dan A. Ljungqvist, 2006, "Investment sentiment and pre-IPO markets”. Journal of Finance 61, 11871216.

Dunbar, Craig G., 2000, "Factors affecting investment bank initial public offering market share”. Journal of Financial Economics 55, 3-41.

Hanley, Weiss Kathleen, A. Arun Kumar, and Paul J. Seguin, 1993, "Price stabilization in the market for new issues". Journal of Financial Economics 34, 177-198.

Kahneman, Daniel, and Amos Tversky, 1979, "Prospect theory: An analysis of decision under Risk”. Econometrica 47, 263-291.

La Porta, Rafael, Florencio Lopez-de-Silanes, Andrei Shleifer, and Robert W. Vishny, 1997, "Legal determinants of external finance”. Journal of Finance 52, 11311150.

Lewellen, Katharina, 2006, "Risk, Reputation, and IPO Price Support”. Journal of Finance, 61, 613-653.

Prabhala, N. R., and Manju Puri, 1999, "How does underwriter price support affect IPOs: Empirical evidence”. Working paper, Yale University and Stanford University.

Ritter, J.R., dan I Welch, 2002, "A review of IPO activity, pricing, and allocations”. Journal of Finance 57, 1795-1828.

Rock, K., 1986, "Why new issues are underpriced”. Journal of Financial Economics 15, 187-212.

Ruud, J.S., 1993, “Underwriter price support and the IPO underpricing puzzle". Journal of Financial Economics 34, 135-151. 
Schultz, Paul H., and Mir A. Zaman, 1994, "Aftermarket support and underpricing of initial public offerings”. Journal of Financial Economics 35, 199-219.

Utamaningsih, Arni, 2012, "Informasi asimetri dalam penjaminan saham IPO di pasar modal Indonesia: Penetapan harga, alokasi saham perdana, underpricing, dan stabilisasi harga", Unpublished Dissertation, Universitas Gadjah Mada.

Wilhelm Jr, William J., 1999, "Secondary Market Stabilization of IPOs". Journal of Applied Corporate Finance 12 (1), 78-85. 